\title{
Integrasi Pesantren dan Sekolah \\ (Kajian atas Pemikiran Abdurrahman Wahid)
}

\author{
Herman Wicaksono \\ UIN Prof. K.H. Saifuddin Zuhri Purwokerto, Indonesia \\ herman@uinsaizu.ac.id
}

DOI: https://doi.org/10.21154/sajiem.v3i1.85

\begin{abstract}
Pesantren and schools should be integrated where they need to work together to improve the quality of education in Indonesia. Asid from the benefits and drawbacks of the pesantren education model, Abdurrahman Wahid, the "child" of pesantren, has demonstrated that pesantren can generate a nation's competent and competitive generation. As a result, the researcher was able to unearth Abdurrahman Wahid's views through library research involving books, kitab, periodicals, journals, and other connected materials. Abdurrahman Wahid has unique ideas regarding pesantren and school integration. Abdurrahman Wahid believes that this integration is critical in eliminating the knowledge divide and meeting the demands of today's career prospects. If the pesantren are still cut off from the new system that has joined the pesantren system, this will be impossible to do.
\end{abstract}

Keywords: integration, pesantren, school, Abdurrahman Wahid

\begin{abstract}
Abstrak
Pesantren dan sekolah harus terintegrasi di mana mereka perlu bekerja sama untuk meningkatkan kualitas pendidikan di Indonesia. Selain kelebihan dan kekurangan model pendidikan pesantren, Abdurrahman Wahid, "anak" pesantren, telah menunjukkan bahwa pesantren dapat menghasilkan generasi bangsa yang kompeten dan berdaya saing. Hasilnya, peneliti mampu menggali pandangan Abdurrahman Wahid melalui studi pustaka yang melibatkan buku, kitab, majalah, jurnal, dan materi terkait lainnya. Abdurrahman Wahid memiliki ide unik tentang integrasi pesantren dan sekolah. Abdurrahman Wahid percaya bahwa integrasi ini sangat penting dalam menghilangkan kesenjangan pengetahuan dan memenuhi tuntutan prospek karir saat ini. Jika pesantren masih terputus dari sistem baru yang telah bergabung dengan sistem pesantren, hal ini tidak mungkin dilakukan.
\end{abstract}

Kata kunci: integrasi, pesantren, sekolah, Abdurrahman Wahid

\section{Pendahuluan}


Indonesia merupakan negeri yang kaya raya termasuk di dalamnya kaya akan sistem pendidikan. Diantara beberapa sistem pendidikan yang berkembang pesat di negeri ini, sistem pendidikan pesantren dan sistem pendidikan sekolah umum atau perkuliahan merupakan yang paling dominan. Pendidikan pesantren sebagai salah satu pendidikan non formal diyakini sebagai sistem pendidikan tertua di Indonesia. Pesantren bahkan telah lahir jauh sebelum lahirnya pendidikan dengan sistem sekolah. Pondok pesantren ini tumbuh sebagai perwujudan dari strategi umat Islam untuk mempertahankan eksistensinya terhadap pengaruh penjajahan Barat dan atau akibat surau atau langgar atau masjid tempat diselenggarakannya pendidikan agama ini tidak lagi dapat menampung jumlah anak-anak yang ingin mengaji. Di samping itu juga didorong oleh keinginan untuk lebih mengintensifkan pendidikan agama pada anakanak. ${ }^{1}$ Adapun pendidikan formal seperti sekolah-sekolah, madrasah-madrasah, maupun pendidikan formal lainnya baru lahir setelah kemerdekaan. Pesantren yang diakui sebagai model pendidikan awal (Islam) di Indonesia sampai saat ini masih eksis dan mampu mempertahankan kredibilitasnya di masyarakat. Meski demikian, beberapa pesantren saat ini bisa dibilang mempunyai peran yang masih terbatas karena kurangnya kredibilitas dan minimnya fasilitas yang dimiliki.

Atas dasar sejarah lahirnya yang jauh sebelum sekolah umum lahir, pesantren sering dianggap sebagai lembaga pendidikan yang tertinggal. Banyak masyarakat beanggapan bahwa pesantren sudah ketinggalan zaman. Hal ini sering terdengar di kalangan masyarakat tertentu yang lebih mengedepankan pada pendidikan formal, khususnya sekolah-sekolah umum. Mereka menganggap bahwa sistem pendidikan yang paling relevan saat ini hanya pendidikan di bangku sekolah atau bangku perkuliahan. Kelompok kedua tak kalah ekstrimnya dengan kelompok sebelumnya. Mereka merupakan kebalikan atau oposisi dari kelompok pertama yang memandang sebelah mata terhadap pendidikan pesantren atau paling tidak mereka menomor duakan pesantren. Kelompok ini justru fanatik dengan kehidupan pesantren dan menolak secara keras adanya pendidikan formal. Mereka beranggapan pendidikan formal seperti sekolah-sekolah dan perkuliahan merupakan tradisi Barat yang tidak sesuai dengan ajaran Islam. Maka dari itu, mereka menolak adanya pencampuran antara pendidikan pesantren dan sekolah umum. Pandangan dan sikap yang cenderung terhadap prioritas dan mengutamakan ilmu agama dilakukan oleh hanya sebagian tokoh atau ulama' sejak mulai merebaknya pertentangan antara ilmu agama dan ilmu filsafat -yang berujung pada sikap resistensi terhadap "ilmu-ilmu umum", bahkan sampai pada "pengharaman" mempelajarinya. ${ }^{2}$

Melihat beberapa opini yang saling berseberangan tersebut, kiranya perlu ada penengah di antara keduanya. Adalah Abdurrahman Wahid salah satu tokoh pembaruan pesantren yang mencoba meluruskan pandangan mereka. Ia secara tersirat berpendapat bahwa antara keduanya adalah sama-sama penting. Dalam bukunya, Abdurrahman Wahid memaparkan bahwa dalam sistem pendidikan agama yang paling eksklusif sekalipun, tidak semua siswanya dapat di-“cetak" menjadi ulama/ahli agama. Oleh karena itu apa salahnya menerima "sekolah umum" dalam lingkungannya? Kepada siswa "sekolah umum" itu dapat diberikan pendidikan agama sebagai kegiatan ekstrakurikuler yang diatur berjenjang, sesuai dengan jenjang "sekolah umum” yang mereka lalui. Sedangkan bagi mereka yang berkeinginan menjadi ulama, masih terbuka kesempatan untuk sepenuhnya mempelajari ilmu - ilmu agama, baik dalam bentuk pendidikan formal di madrasah maupun dalam bentuk pengajian sebagai pendidikan nonformal. ${ }^{3}$

Melihat pandangan Abdurrahman Wahid di atas, tampak betapa ia adalah seorang tokoh yang sangat moderat. Meskipun ia dilahirkan dan dibesarkan di kalangan pesantren, namun tidak serta merta ia fanatik terhadap pesantren apalagi sampai ia menolak adanya

${ }^{1}$ S Sadali, "Eksistensi Pesantren Sebagai Lembaga Pendidikan Islam," Atta'dib Jurnal Pendidikan Agama Islam, 2020.

${ }^{2}$ Baharuddin, dkk, Dikotomi Pendidikan Islam (Bandung: Remaja Rosdakarya, 2011), 234.

${ }^{3}$ Abdurrahman Wahid, Menggerakkan Tradisi Esai-Esai Pesantren (Yogyakarta: LKiS, 2010), 69. 
sekolah umum. Abdurrahman Wahid berpendapat bahwa pendidikan Islam memiliki begitu banyak model pengajaran, baik yang berupa pendidikan sekolah, maupun "pendidikan non-formal" seperti pengajian, arisan dan sebagainya. Tak terhindarkan lagi, keragaman jenis dan corak pendidikan Islam terjadi seperti terlihat di tanah air tercinta dewasa ini. Ketidakmampuan memahami kenyataan ini, yaitu melihat bahwa lembaga pendidikan formal seperti sekolah dan madrasah-madrasah di tanah air sebagai satu-satunya institusi pendidikan Islam, hanyalah akan mempersempit pandangan tentang pendidikan Islam itu sendiri. Ini berarti, pandangan semacam itu hanya mementingkan satu sisi belaka dari pendidikan Islam yaitu pendidikan formal, dan melupakan sisi lain dari pendidikan Islam yakni pendidikan non-formal. Tentu saja ini menjadi tugas berat para perencana pendidikan Islam. Kenyataan ini menunjukkan di sinilah terletak lokasi perjuangan pendidikan Islam. Dalam kenyataan ini haruslah diperhitungkan juga. ${ }^{4}$

Oleh karenanya, dirasa penting bagi penulis untuk memaparkan pokok-pokok pikiran Abdrurrahman Wahid mengenai integrasi pendidikan pesantren dan sekolah khususnya sekolah umum. Adapun yang melatarbelakangi penulis untuk mengambil pemikiran Abdurrahman Wahid meskipun ada beberapa tokoh lain seperti Nurcholis Madjid dan Zamakhsyari Dhofier adalah karena pemikirannya yang penulis anggap unik. Unik dalam hal ini karena Abdurrahman Wahid merupakan salah satu tokoh yang lahir dan tumbuh di lingkungan pesantren, namun ia tidak fanatik dengan pesantren apalagi sampai menolak sekolah umum, akan tetapi ia justru sangat mendukung adanya sekolah-sekolah umum di lingkungan pesantren bahkan kalau bisa sekolah tersebut menjadi bagian dari pesantren tersebut.

\section{Metode Penelitian}

Jenis penelitian yang akan digunakan dalam penelitian ini adalah library research (penelitian kepustakaan). Disebut penelitian kepustakaan karena data-data atau bahan-bahan yang diperlukan dalam menyelesaikan penelitian tersebut berasal dari perpustakaan baik berupa buku, ensklopedi, kamus, jurnal, dokumen, majalah dan lain sebagainya. ${ }^{5}$ Oleh karenanya, objek penelitiannya adalah berupa buku-buku, kitab-kitab, majalah, jurnal serta tulisan lain yang dapat memberikan informasi sesuai dengan kebutuhan penulis.

Sesuai dengan jenis penelitian yang akan penulis lakukan, maka metode pengumpulan data yang digunakan adalah metode dokumentasi. Dokumentasi merupakan teknik pengumpulan data yang dilakukan oleh peneliti guna mengumpulkan data dari berbagai macam hasil media cetak yang membahas mengenai narasumber yang akan diteliti. ${ }^{6}$ Setelah data terkumpul selanjutnya dipilih dan dipilah serta diklasifikasikan untuk kemudian dilakukan analisis data.

Metode analisis data yang penulis gunakan dalam penelitian ini adalah metode Content Analysis. Metode Content Analysis adalah metode yang digunakan untuk menarik simpulan dengan menemukan karakteristik pesan yang dilakukan secara sistematis dan obyektif. ${ }^{7}$ Dalam hal ini penulis telah menganalisa pendapat-pendapat Abdurrahman Wahid berkaitan dengan integrasi pendidiakan madrasah dan sekolah.

\section{Temuan dan Pembahasan}

${ }^{4}$ Abdurrahman Wahid, Islamku, Islam Anda, Islam Kita (Jakarta: The Wahid Institute, 2006), 226.

${ }^{5}$ Herman Wicaksono, "Tujuan Pendidikan Islam Berbasis Mabadi Khaira Ummah," Edukasia Islamika 5, no. 1 (2020): 17-37, doi:https://doi.org/10.28918/jei.v5i1.2426.

${ }^{6}$ Suci Arischa, "Analisis Beban Kerja Bidang Pengelolaan Sampah Dinas Lingkungan Hidup Dan Kebersihan Kota Pekanbaru," Jurnal Online Mahasiswa Universitas Riau 6, no. 1 (2019).

${ }^{7}$ Wicaksono, "Tujuan Pendidikan Islam Berbasis Mabadi Khaira Ummah." 


\section{Pandangan Abdurrahman Wahid tentang Integrasi Pesantren dan Sekolah Umum}

Mengenai integrasi antara pesantren dan sekolah umum ini, Abdurrahman Wahid telah menyebutkan dalam salah satu buku yang ia tulis,

... telah tibalah saaatnya bagi kita semua untuk merancanakan dan melaksanakan pembentukan "sekolah-sekolah umum" secara meluas dalam lingkungan pesantren dengan cara sebaik-baiknya dan berhati-hati. Kita semuanya lah yang akan memetik hasil dari program semacam itu dalam jangka panjang, terutama dari segi hilangnya dualisme pendidikan di negeri kita secara berangsur-angsur, terutama tanpa merugikan pihak manapun yang bersangkut paut dengan dunia pendidikan itu sendiri. ${ }^{8}$

Abdurrahman Wahid tidak menyebutkan secara tersurat bahwa ia menginginkan adanya integrasi antara kedua sistem pendidikan di Indonesia, akan tetapi dari pernyataan ia, dapat diambil suatu kesimpulan bahwa ia adalah salah satu tokoh yang mendukung adanya intergasi ini. Dalam kutipan di atas, secara jelas ia menghimbau kepada seluruh lapisan masyarakat khususnya pemerintah untuk mulai membentuk sekolah-sekolah umum di lingkungan pesantren. Adapun sekolah-sekolah umum yang dimaksudkan Abdurrahman Wahid adalah sekolah-sekolah yang tidak berorientasi pada keagamaan seperti SD, SMP, dan SMA. ${ }^{9}$

Sebagai seorang tokoh yang lebih dikenal sebagai politikus, pandangannya terhadap dunia pendidikan sangat patut untuk didalami. Hal ini karena tidak banyak tokoh yang tatkala ia dikenal sebagai seorang tokoh tertentu masih mau peduli terhadap aspek atau bidang lain. Sebagai seorang tokoh yang dikenal memilki sikap toleransi sangat tinggi, tampaknya sikap itu pun muncul ketika ia membahas persoalan pendidikan. Pernyataannya yang tidak menghendaki adanya pihak yang merasa dirugikan menjadi indikasi bahwa ia senantiasa menjunjung tinggi toleransinya. Meskipun apa yang menjadi pandangannya dinilai sangat bagus, akan tetapi tidak serta merta ia memaksakan pendapatnya.

Bukti lain bahwa ia mendukung adanya integrasi antara pesantren dan sekolah adalah adanya pandangan bahwa pesantren harus maju dan mampu bersaing di era yang serba modern. Untuk bisa bersaing di era modern ini, sebuah pesantren harus mampu mengimbangi perkembangan zaman. Namun demikian, pesantren sebagi lembaga pendidikan yang independen harus tetap menjaga keautentukan atau ciri khas pesantren itu sendiri.

\section{Pelaksanaan Integrasi Pendidikan Pesantren dan Sekolah menurut Abdurrahman Wahid}

\section{Integrasi Kurikulum}

Kurikulum yang berkembang di dunia pesantren selama ini memperlihatkan pola yang tetap. Pola itu dapat diringkas ke dalam pokok-pokok berikut: (a) kurikulum ditujukan untuk "mencetak" ulama di kemudian hari; (b) struktur dasar kurikulum itu adalah pengajaran pengetahuan agama dalam segenap tingkatannya dan pemberian pendidikan dalam bentuk bimnbingan kepada santri secara pribadi oleh guru/kiai. (c) secara keseluruhan, kurikulum yang ada bersifat lentur atau fleksibel, yaitu dalam setiap kesempatan para santri memiliki kesempatan untuk menyusun kurikulumnya sendiri sepenuhnya atau sebagian sesuai dengan kebutuhan dan kemampuannya, bahkan pada pesantren yang memilki sistem pendidikan berbentuk sekolah sekalipun. ${ }^{10}$

Sepintas lalu, kenyataan ini menimbulkan penilaian negatif atas kemampuan pesantren menyediakan tenaga terdidik yang sesuai dengan kebutuhan lapangan kerja masyarakat modern. Dengan jumlah santrinya yang mencapai jutaan jiwa, ketidak mampuan pesantren untuk menyediakan tenaga terlatih untuk lapangan kerja yang membutuhkan spesialisasi tampaknya harus disayangkan. Ketiadaan arah jelas bagi kurikulumnya dalam hubungannya dengan penyediaan angkatan kerja tampaknya harus dicemaskan, apa lagi bila dihubungkan

\footnotetext{
${ }^{8}$ Wahid, Menggerakkan Tradisi Esai-Esai Pesantren, 70.

${ }^{9}$ Ibid, 66.

${ }^{10}$ Ibid, 145 .
} 
dengan sedikitnya persediaan tenaga terlatih untuk lapangan-lapangan kerja khusus, karena masih terbatasnya pendidikan kejuruan di Indonesia. Konsekuensi logis dari anggapan ini adalah kehendak dan harapan agar pesantren bersedia membuka diri bagi pendidikan yang lebih menjurus dalam hubungannya dengan penyediaan angkatan kerja. "

Selain pemikirannya tentang kebebasan santri dalam membuat kurikulum sendiri, Abdurrahman Wahid juga menginginkan agar kurikulum pesantren memilki keterkaitan dengan kebutuhan lapangan kerja. Di lingkungan kerja, baik jasa, perdagangan, maupun keahlian lainnya, pesantren harus mampu berkontribusi bagi dunia pendidikan perihal kompetensi dibutuhkan oleh dunia kerja yang di era globalisasi seperti sekarang ini berkmbang begitu cepat beragam. ${ }^{12}$

Pada saat ini, pesantren 'dipaksa' memasuki ruang kontestasi dengan institusi pendidikan lainnya. Kompetisi yang kian ketat dalam penyelenggaraan pendidikan di Indonesia memosisikan institusi pesantren untuk mempertaruhkan kualitas output pendidikannya agar tetap unggul dan menjadi pilihan masyarakat, terutama umat Islam. Maka dari itu, untuk mampu memenuhi kebutuhan lapangan kerja yang ada di era modern ini, tentu akan sulit jika pesantren terus-terusan menutup diri dari sistem baru yang masuk ke dalamnya. Sebagai terobosan, pesantren sangat memerlukan lahirnya sekolah umum di dalamnya. Hal ini karena mau tidak mau, dunia kerja di Indonesia hanya mau mengakui mereka yang mempunyai ijazah pendidikan formal. Oleh karenanya, agar pesantren bisa turut andil dalam memenuhi kebutuhan lapangan kerja yang ada, perlu kiranya lahir suatu lembaga pendidikan yang bisa memfasilitasi keinginan ini.

Dasar dari program ini adalah penilaian lebih baik bagi pesantren untuk mendirikan sekolah-sekolah non-agama dalam lingkungannya dari pada bertindak setengah-setengah seperti kebanyakan pesantren dengan berbagai jenis madrasah mereka. ${ }^{13}$ Tanpa menafikan madrasah, ia lebih mengutamakan pendirian sekolah umum dengan tujuan agar transfer ilmuilmu umum atau non-agama lebih efektif. Sedangkan untuk transfer ilmu-ilmu agama sudah sangat jelas bisa didapat peserta didik melalui pesantren itu sendiri. Sebagai program yang mengintegrasikan sekolah non agama ke dalam sistem pendidikan pesantren tradisional, diharapkan para santri yang mengikutinya akan menguasai pengetahuan dasar tentang agama pada waktu mereka menyelesaikan sekolah non-agama mereka di pesantren. ${ }^{14}$

Seiring dengan perubahan arah kurikulum tersebut di atas, Abdurrahman Wahid juga menekankan pentingnya menghilangkan dikotomi antara ilmu agama dan ilmu umum, dengan catatan penguasaan ilmu agama harus diberi porsi yang cukup besar dalam kurikulum pesantren tersebut. Porsi tersebut dapat diberikan secara kualitatif dan bukan dalam segi kuantitatif. Dengan kata lain, menurut Abuddin Nata sebagaimana dikutip oleh Abdullah, modernisasi kurikulum pesantren harus tetap berada pada jati dirinya, karena dengan cara demikian itu lah, dunia pesantren tidak akan kehilangan jati dirinya. Namun demikian, semua itu pada akhirnya kembali kepada kemauan pengelolanya. ${ }^{15}$

\section{Integrasi Tujuan Pendidikan}

\footnotetext{
${ }^{11}$ Ibid, 146.

${ }^{12}$ Muhammad Hasyim, "Modernisasi Pendidikan Pesantren Dalam Perspektif Kh. Abdurrahman Wahid," Cendekia : Jurnal Studi Keislaman 2, no. 2 (2018), doi:10.37348/cendekia.v2i2.27.

${ }^{13}$ Wahid, Menggerakkan Tradisi Esai-Esai Pesantren, 155.

${ }^{14}$ Ibid.

15 Abdullah Abdullah, "Kurikulum Pesantren Dalam Perspektif Gus Dur; Suatu Kajian Epistemologis," Jurnal Pendidikan Agama Islam (Journal of Islamic Education Studies) 4, no. 2 (2016), doi:10.15642/pai.2016.4.2.227-248.
} 
Di Indonesia, tujuan pendidikan dirumuskan dalam sebuah rumusan yang disebut tujuan pendidikan nasional sebagaimana yang termaktub dalam Undang-Undang Sistem Pendidikan Nasional Nomor 20 Tahun 2003. Dalam undang-undang tersebut disebutkan bahwa "Pendidikan nasional berfungsi mengembangkan kemampuan dan membentuk watak serta peradaban bangsa yang bermartabat dalam rangka mencerdaskan kehidupan bangsa, bertujuan untuk berkembangnya potensi peserta didik agar menjadi manusia yang beriman dan bertakwa kepada Tuhan Yang Maha Esa, berakhlak mulia, sehat, berilmu, cakap, kreatif, mandiri, dan menjadi warga negara yang demokratis serta bertanggungjawab" ${ }^{16}$

Selain tujuan pendidikan secara umum sebagaimana telah disebutkan di atas, ada juga tujuan pendidikan Islam secara khusus. Adapun tujuan pendidikan Islam adalah

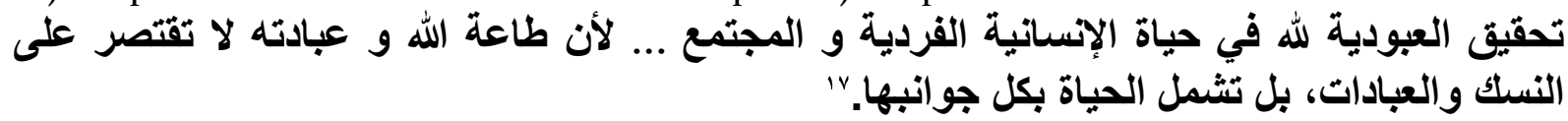

Dari sini sangat jelas bahwa tujuan pendidikan Islam adalah untuk beribadah kepada Allah. Namun meskipun demikian, perlu dipahami bahwa beribadah kepada Allah tidak lah hanya ibadah mahdah saja, tetapi juga ada ibadah gairu mahdah. Diantara ibadah gairu mahdah yang dapat bernilai ibadah adalah mencari nafkah. Sedangkan untuk mencari nafkah khususnya di negeri ini, hampir mayoritas mengutamakan lulusan yang mengenyam pendidikan formal, sehingga dari sini dinilai penting adanya sekolah umum di lingkungan pesantren. Tujuannya tidak lain adalah untuk mengimbangi pesantren yang mana pesantren merupakan pusat untuk secara khusus mengkaji berbagai bentuk ibadah mahdah.

Mengenai tujuan pendidikan, khususnya tujuan pendidikan pesantren, Abdurrahman Wahid berpendapat bahwa tujuan pendidikan pesantren bukan hanya terletak pada upaya tafaqquh fi al-dìn, yakni tidak hanya menghasilkan manusia yang mendalami ilmu agama setingkat ulama, melainkan terintegrasinya pengetahuan agama dan non-agama, sehingga lulusan yang dihasilkan pesantren adalah suatu kepribadian yang utuh dan bulat dalam dirinya, yakni pribadi yang di dalamnya tergabung unsur-unsur keimanan yang kuat atas pengetahuuan secara seimbang. ${ }^{18}$. Dari sini tampak jelas bahwa tujuan pendidikan menurut Abdurrahman Wahid adalah mencetak output yang cerdas akal dan cerdas spiritual.

Tujuan tersebut secara jelas menggambarkan adanya keinginan dari pesantren agar mampu menggabungkan antara pendalaman pemahaman agama dan pemahaman pengetahuan umum. Telebih lagi, dicanangkannya tujuan tersebut dibrengi dengan adanya usaha nyata berupa pendirian sekolah-sekolah umum di lingkungan pesantren. Dengan demikian, diharapkan lulusan yang dihasilkan benar-benar lulusan yang sesuai dengan kebutuhan lapangan pekerjaan.

\section{Integrasi Konsep Peserta Didik dan Sistem Pendidikan}

Peserta didik adalah anggota masyarakat yang berusaha mengembangkan potensi diri melalui proses pembelajaran yang tersedia pada jalur, jenjang, dan jenis pendidikan tertentu (UU Sisdiknas). Dari definisi tersebut, dapat diambil pemahaman bahwa asalkan seseorang sedang menempuh suatu jalur, jenjang, dan jenis tertentu baik foemal maupun nonfoemal, maka seseorang tersebut bisa disebut sebagai peserta didik. Istilah peserta didik identik digunakan dalam lembaga-lembaga pendidikan formal. Sedangkan dalam lembaga pesantren, peserta didik disebut dengan istilah santri.

Di masyarakat pedesaan khususnya di wilayah Jawa, ada sekelompok masyarakat muslim yang disebut santri. Sebutan ini disematkan kepada mereka yang taat menjalankan

${ }^{16}$ Undang-Undang Republik Indonnensia Nomor 20 Tahun 2003 tentang Sistem Pendidikan Nasional (2003).

${ }^{17}$ Abdurrahman An-Nahlawi, Usul Al-Tarbiyyah Al-Islmiyyah Wa Asalibuha Fi Al-Baiti Wa AlMadrasati Wa Al Mujtama’i (Damaskus: Dar al-Fikr, 2004), 90.

${ }^{18}$ Abuddin Nata, Tokoh-Tokoh Pembaruan Pendidikan Islam Di Indonesia (Jakarta: Raja Grafindo Persada, 2005), 357. 
perintah agamanya yaitu Islam. Menurut Rizki sebagaimana dikutip oleh Mansur Hidayat, setidaknya ada 2 pendapat yang dapat digunakan sebagai rujukan. Pertama, santri berasal dari dari kata "Santri" yang dalam bahasa Sansekerta Ini berarti melek huruf. Kedua, dari bahasa Jawa "Cantrik" yang artinya seseorang yang mengikuti guru di manapun guru itu berada. Tujuannya adalah untuk dapat belajar sesuatu darinya. ${ }^{19}$ Adapun dalam tulisan ini, makna kedua lah yang menjadi pembahasan penulis. Sekelompok peserta dalam makna santri yang kedua mengandung maksud sekelompok peserta didik. Dengan demikian jelas bahwa santri juga peserta didik, hanya saja istilah santri terkhusus untuk dunia pesantren.

Abdurrahman Wahid menginginkan agar peserta didik yang belajar di pesantren adalah peserta didik yang memilki ilmu agama yang kuat dan sekaligus juga memilki ilmu umum yang kuat secara seimbang. Abdurrahman Wahid menginginkan, agar disamping mencetak ahli ilmu agama Islam, pesantren juga mampu mencetak orang yang memiliki keahlian dalam ilmu pengetahuan dan teknologi, seperti ilmu komputer, fisika, pertanian, perkebunan, dan sebagainya. ${ }^{20}$ Contoh konkret dari adanya integrasi antara pendidikan pesantren dan sekolah umum adalah sebagaimana pesantren yang pernah membesarkan namanya, yang merupakan pesantren yang didirikan oleh kakeknya dari jalur ayah, KH. Hasyim Asy'ari yaitu Pondok Pesantren Tebuireng Jombang. Pesantren ini telah melakukan integrasi antara pesantren dan sekolah dalam berbagai aspek seperti kurikulum, tujuan pendidikan, dan peserta didik. Hal tersebut terbukti dengan integrasi tersebut bukannya menyurutkan perkembangan pesantren, tetapi justru senantiasa berkembang dari waktu ke waktu.

Dalam 30 tahun pertama, tujuan pendidikan Tebuireng ialah untuk mendidik calon ulama. Sekarang ini, tujuan pendidikan Tebuireng sudah diperluas, yaitu untuk mendidik para santri agar kelak dapat mengembangkan dirinya sendiri menjadi "ulama intelektual" (ulama yang menguasai pengetahuan umum) dan "intelektual ulama" (sarjana dalam bidang pengetahuan umum yang juga menguasai pengetahuan Islam) ${ }^{21}$ Untuk mengejar kedua tujuan tersebut, Tebuireng menyelenggarakan 10 macam tipe aktivitas pendidikan: (1) Kelas Bandongan, (2) Madrasah Ibtidaiyyah, (3) Sekolah Persiapan Tsanawiyyah, (4) Madrsah Tsanawiyyah, (5) Madrasah 'Aliyyah, (6) SMP, (7) SMA, (8) Madrsah Al Huffadh, (9) Jam'iyyah dan (10) Universitas Hasyim Asy'ari (Dhofier, 2011: 186). Dari sini terlihat jelas betapa sebuah pesantren yang menerapkan konsep integrasi begitu baik. Di pesantren ini lah Abdurrahman Wahid dilahirkan dan tumbuh menjadi orang yang penuh pemikiran meskipun ia tak selamanya tinggal disana. Tapi paling tidak contoh di atas menggambarkan betapa integrasi kurikulum antara pesantren dan sekolah umum jika dikelola dengan maksimal justru akan menambah kekayaan intelektual pesantren itu sendiri.

\section{Pentingnya Integrasi Pesantren dan Sekolah Umum Menurut Abdurrahman Wahid}

Integrasi pendidikan pesantren dan sekolah umum selain sebagai suatu proses tersendiri juga menjadi sebab atau lantaran yang sangat menentukan perkembangan komponen agama dan nonagama dalam suatu pesantren. Sebagai salah satu contoh pengembangan komponen yang dilakukan oleh sebagian pesantren dalam ranah kurikulumnya, yaitu dengan jalan mendirikan sekolah-sekolah nonagama dalam lingkungan pesantren sendiri. Sekolah nonagama seperti SMP dan SMA didirikan di lingkungan pesantren secara utuh dan apa adanya sesuai dengan kurikulum sekolah-sekoah lain di luar pesantren. ${ }^{22}$ Akan tetapi, hal itu hanya baru dilakukan oleh sebagian pesantren saja, sedangkan sebagian yang lain masih merasa kesulitan untuk mengembagkan kedua komponen ini, sehingga

${ }^{19}$ Mansur Hidayat, "Model Komunikasi Kyai Dengan Santri Di Pesantren," Jurnal ASPIKOM 2, no. 6 (2017), doi:10.24329/aspikom.v2i6.89.

${ }^{20}$ Nata, Tokoh-Tokoh Pembaruan Pendidikan Islam Di Indonesia, 353.

${ }^{21}$ Zamakhsyari Dhofier, Tradisi Pesantren Studi Pandangan Hidup Kyai Dan Visinya Mengenai Masa Depan Indonesia, LP3ES ed. (Jakarta, 2011), 185.

${ }^{22}$ Wahid, Menggerakkan Tradisi Esai-Esai Pesantren, 187. 
akibatnya ada beberapa kesalahan yang dilakukan oleh pesantren dalam upaya pengembangan ini.

Menurut Abdurrahman Wahid, ada beberapa kesalahan dasar dalam upaya pengembangan komponen non agama di pesantren selama ini, yaitu:

a. Sifat upaya itu sendiri, yang lebih banyak ditekankan pada intelektualisme verbalistis yang penuh dengan teori yang muluk-muluk namun tak mampu memecahkan persoalanpersoalan praktis yang terjadi di depan mata. ${ }^{23}$ Dengan terlalu banyaknya teori, terkadang peserta didik hanya terfokuskan pada pengetahuan yang bersifat kognitif, padahal, dalam suatu pembelajaran hatus mencakup tiga ranah yaitu kognitif, afektif, dan psikomotorik. Terlebih lagi, sekarang ini Indonesia tengah mencanangkan Kurikulum 2013 yang lebih mengutamakan aspek afektif dari pada kognitif. Salah satu fokus pengembangan Kurikulum 2013 adalah pembentukan kompetensi dan karakter peserta didik, berupa paduan pengetahuan, keterampilan dan sikap yang dapat didemonstrasikan peserta didik sebagai wujud pemahaman terhadap konsep yang dipelajarinya secara kontekstual. ${ }^{24}$ Pendemonstrasian pengetahuan sebagai wujud pemahaman akan sulit dilakukan jika pihak penyelenggara pendidikan belum bisa mengarahkan para peserta didiknya ke arah sana. Sehingga, semuluk-muluk apa pun materi yang disampaikan, jika tidak diimbangi dengan upaya penerapan di lapangan termasuk di dalamnya pemecahan permasalahan, maka tujuan pendidikan akan sulit tercapai. Hal ini juga lah yang masih menjadi sifat pembelajaran di pesantren. Oleh karenanya, agar para lulusan pesantren mampu memecahkan persoalan-persoalan di lapangan harus ada upaya untuk membuka diri sehingga semakin tahu bagaimana kondisi lapangan yang sesungguhnya.

b. Penanganan kurikulum dan komponen-komponennya secara sepotong-potong, tidak menggunakan pendekatan menyeluruh yang bersifat multidisipliner (yang terbukti anatara lain dalam pemisahan antara pengetahuan sosial ekonomi, sosial budaya, dan pengetahuan alam).$^{25}$ Aplikasi pendekatan ini dalam pesantren dan sekolah dapat berupa penggabungan berbagai disiplin ilmu baik agama maupun nonagama dalam rangka mencetak alumni yang siap terjun di tengah masyarakat. Dengan bekal berbagai disiplin ilmu yang memadai, diharapkan para alumni atau lulusan tidak merasa kaget ketika menghadapi tantangan secara langsung di kejhidupan mereka. Hal ini katrena mereka telah terbiasa dengan berbagai disiplin ilmu sewaktu mereka belajar baik ilmu teoritis maupun praktis.

c. Belum tercapainya kesatuan (integrasi) yang utuh dan bulat antara komponen-komponen agama dan nonagama. ${ }^{26}$ Dengan adanya integrasi ini diharapkan akan lahir suatu pengembangan baru yang terjadi di dunia pesantren dan juga sekolah umum. Integrasi yang di harapkan tidak hanya terjadi pada pesantren, namun juga terjdi pada sekolah umum. Pesantren yang telah terintegrasi nantinya akan mau dan mudah menerima masukan dari luar selama hal itu demi kemajuan pesantren, demikian juga, sekolah umum yang terintegrasi nantinya akan mudah untuk bekerja sama dengan pesantren serta berjalan bersama guna mencapai tujuan pendidikan yang terpadu. Ttujuan pengembangan pesantren dengan demikian adalah integrasi antara pengetahuan agama dan nonagama sehingga lulusan yang dihasilkan akan memilki suatu kepribadian yang utuh dan bulat, yang menggabungkan dalam dirinya unsur-unsur keimanan yang kuat dan penguasaan atas pengetahuan secara berimbang. Manusia yang sedemikian itu memilki cakrawala pemikiran yang luas, pandangan hidup yang matang, dan pendekatan yang praktis dan berwatak multisektoral dalam memecahkan persoalan-persoalan yang dihadapi. Dengan

${ }^{23}$ Ibid, 185 .

${ }^{24}$ E. Mulyasa, Pengembangan Dan Implementasi Kurikulum 2013 (Bandung: PT. Remaja Rosdakarya., 2014), 65.

${ }^{25}$ Wahid, Menggerakkan Tradisi Esai-Esai Pesantren, 185.

${ }^{26}$ Ibid. 
kata lain manusia yang mampu memandang jauh ke muka sekaligus memilki keterampilan praktis untuk menyelesaikan persoalan sendiri secara terbatas. ${ }^{27}$

\section{Analisis Pemikiran Abdurrahman Wahid tentang Integrasi antara Pendidikan Pesantren dan Sekolah}

Tidaklah mudah untuk bisa menganalisis pemikiran seseorang. Terkadang ketika menafsirkan suatu pemikiran dari seorang tokoh, seseorang harus benar-benar mampu memahami jalan pikiran tokoh tersebut. Begitu pula dengan Abdurrahman Wahid, untuk bisa memahami pemikirannya, setiap orang yang hendak menafsiri pemikirannya haruslah benarbenar memahami apa yang menjadi jalan pikirannya. Dalam banyak kesan, Abdurrahman Wahid mungkin bisa digambarkan dengan kata-kata yang singkat saja: kompleks dan nyleneh. Oleh karena itu, pribadi Abdurrahman Wahid cenderung sulit untuk dipahami, terutama dalam satu sudut tafsir atas dua kata itu, tergantung siapa yang melihat dan memahami. Bahkan pada saat ia menjabat sebagai Presiden RI, sempat muncul anekdot tentang tiga misteri Tuhan: bahwa ada tiga misteri Tuhan yang tidak bisa dipahami atau diketahui manusia sebelum hal itu terjadi, yakni jodoh, kematian, dan Gus Dur (Abdurrahman Wahid). Bagi orang awam dan para pengikutnya, bahkan bagi ilmuwan yang intelek sekalipun, Gus Dur sering kali dilihat sebagai pribadi yang misterius, tak tertuga, dan weruh sak durunge winarah (bisa mengetahui sesuatu sebbelum sesuatu itu terjadi)—sebuah kata-kata Jawa yang memilki makna sangat dalam, sarat dengan hikmah dan misteri.

Selama ini kebanyakan orang memahami atau mengenal Abdurrahman Wahid sebagai seorang tokoh politik dan negarawan. Terkadang juga ada yang mengenalnya sebagai budayawan, disamping ia juga dikenal sebagai seorang tokoh yang senantiasa gencar dalam membumikan pluralisme dan toleransi. Akan tetapi, di samping smua itu, ia juga layak disebut sebagai seorang tokoh pendidikan, khususnya di Indonesia. Sebutannya sebagai tokoh pendidikan bukanlah tanpa alasan atau tanpa sebab. Beberapa hal tentu menjadi sebab mengapa ia dikenal sebagai tokoh pendidikan, diantaranya, dilihat dari segi latar belakan pendidikan, Abdurrahman Wahid adalah seorang tokoh yang memilki pengalaman belajar yang lengkap antara pendidikan agama dan pendidikan umum. ${ }^{28}$ Pendidikan agamanya tidak lain ia peroleh selama nyantri di berbagai pesantren semenjak ia kecil hingga dewasa, ditambah dengan pendidikan formalnya di Universitas Al Azhar Kairo Mesir dan Universitas Baghdad. Sedangkan pendidikan umumnya tidaklah sebagaimana perjalanan pendidikan kebanyakan tokoh. Pendidikan umum Abdurrahman Wahid lebih banyak diperolehnya secara otodidak melalui diskusi-diskusi, membaca buku, serta keaktifannya dalam organisasi baik sosial, ekonomi, politik, dan lain sebagainya.

Gagasan dan pemikiran Abdurrahman Wahid dalam bidang pendidikan secara signifikan berkisar pada modernisasi pendidikan pesantren. Secara sepintas, hal ini tidaklah asing mengingat ia adalah salah satu tokoh yang lahir dari dunia pesantren. Akan tetapi, ada sesuatu yang menarik penulis sehingga penulis berkeinginan untuk menelitinya, yaitu ghirrahnya untuk mengembangkan pesantren modern.

\section{Kesimpulan}

Integrasi pendidikan pesantren dan sekolah ini bukan hanya sekedar bagaimana kedua institusi pendidikan ini bersatu, namun lebih jauh dari itu yang lebih penting adalah bagaimana keduanya bisa saling membutuhkan untuk sama-sama meningkatkan kualitas pendidikan di Indonesia. Menurut Abdurrahman Wahid, integrasi kedua lembaga pendidikan ini adalah bertujuan untuk menghilangkan dualisme pendidikan dan sebagai upaya untuk mampu memenuhi kebutuhan lapangan kerja yang ada di era modern ini. Hal ini karena

\footnotetext{
${ }^{27}$ Ibid, $185^{-186 .}$

${ }^{28}$ Nata, Tokoh-Tokoh Pembaruan Pendidikan Islam Di Indonesia, 358.
} 
disadari maupun tidak, lapangan pekerjaan di Indonesia hampir semuanya melihat tingkat pendidikan formalnya.

Ada beberapa pelaksanaan integrasi yang disampaikan oleh Abdurrahman Wahid, yaitu integrasi kurikulum, integrasi tujuan pendidikan, dan integrasi konsep peserta didik. Kesemuanya itu tidak mungkin untuk berjalan sendiri-sendiri, melainkan harus adanya kesinambungan sehingga akan tercipta bentuk integrasi yang utuh antara pendidikan pesantren dan sekolah umum.

\section{Daftar Pustaka}

Abdullah, Abdullah. "Kurikulum Pesantren Dalam Perspektif Gus Dur; Suatu Kajian Epistemologis." Jurnal Pendidikan Agama Islam (Journal of Islamic Education Studies) 4, no. 2 (2016). doi:10.15642/pai.2016.4.2.227-248.

An-Nahlawi, Abdurrahman. Usul Al-Tarbiyyah Al-Islmiyyah Wa Asalibuha Fi Al-Baiti Wa AlMadrasati Wa Al Mujtama’i. Damaskus: Dar al-Fikr, 2004.

Arischa, Suci. “Analisis Beban Kerja Bidang Pengelolaan Sampah Dinas Lingkungan Hidup Dan Kebersihan Kota Pekanbaru.” Jurnal Online Mahasiswa Universitas Riau 6, no. 1 (2019).

Baharuddin, and dkk. Dikotomi Pendidikan Islam. Bandung: Remaja Rosdakarya, 2011.

Dhofier, Zamakhsyari. Tradisi Pesantren Studi Pandangan Hidup Kyai Dan Visinya Mengenai Masa Depan Indonesia. LP3ES ed. Jakarta, 2011.

Hasyim, Muhammad. "Modernisasi Pendidikan Pesantren Dalam Perspektif Kh. Abdurrahman Wahid." Cendekia :Jurnal Studi Keislaman 2, no. 2 (2018). doi:10.37348/cendekia.v2i2.27.

Hidayat, Mansur. "Model Komunikasi Kyai Dengan Santri Di Pesantren.” Jurnal ASPIKOM 2, no. 6 (2017). doi:10.24329/aspikom.v2i6.89.

Mulyasa, E. Pengembangan Dan Implementasi Kurikulum 2013. Bandung: PT. Remaja Rosdakarya., 2014.

Nata, Abuddin. Tokoh-Tokoh Pembaruan Pendidikan Islam Di Indonesia. Jakarta: Raja Grafindo Persada, 2005.

Sadali, S. "Eksistensi Pesantren Sebagai Lembaga Pendidikan Islam." Atta'dib Jurnal Pendidikan Agama Islam, 2020.

Undang-Undang Republik Indonnensia Nomor 20 Tahun 2003 tentang Sistem Pendidikan Nasional (2003).

Wahid, Abdurrahman. Islamku, Islam Anda, Islam Kita. Jakarta: The Wahid Institute, 2006.

_——. Menggerakkan Tradisi Esai-Esai Pesantren. Yogyakarta: LKiS, 2010.

Wicaksono, Herman. “Tujuan Pendidikan Islam Berbasis Mabadi Khaira Ummah.” Edukasia Islamika 5, no. 1 (2020): 17-37. doi:https://doi.org/10.28918/jei.v5i1.2426. 